\title{
Primary production of the northern Barents Sea
}

\author{
ELSE NØST HEGSETH
}

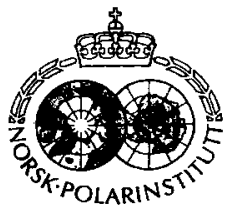

Hegseth, E. N., 1998: Primary production in the northern Barents Sea. Polar Research 17(2), 113-123.

The majority of the arctic waters are only seasonally ice covered; the northern Barents Sea, where freezing starts at 80 to $81^{\circ} \mathrm{N}$ in September, is one such area. In March, the ice cover reaches its greatest extension $\left(74-75^{\circ} \mathrm{N}\right)$. Melting is particularly rapid in June and July, and by August the Barents Sea may be ice free. The pelagic productive season is rather short, 3 to 3.5 months in the northern part of the Barents Sea (north of the Polar Front, $75^{\circ} \mathrm{N}$ ), and is able to sustain an open water production during only half of this time when a substantial part of the area is free of ice. Ice algal production starts in March and terminates during the rapid melting season in June and July, thus equalling the pelagic production season in duration.

This paper presents the first in situ measurements of both pelagic and ice-related production in the northern Barents Sea: pelagic production in summer after melting has started and more open water has become accessible, and ice production in spring before the ice cover melts. Judged by the developmental stage of the plankton populations, the northern Barents Sea consists of several sub-areas with different phytoplankton situations. Estimates of both daily and annual carbon production have been based on in situ measurements. Although there are few sampling stations $(6$ phytoplankton stations and 8 ice-algae stations), the measurements represent both pelagic bloom and non-bloom conditions and ice algal day and night production. The annual production in ice was estimated to $5.3 \mathrm{~g} \mathrm{C} \mathrm{m}^{-2}$, compared to the pelagic production of 25 to $30 \mathrm{~g} \mathrm{C} \mathrm{m}^{-2}$ south of Kvitøya and 12 to $15 \mathrm{~g} \mathrm{C} \mathrm{m}^{-2}$ further north. According to these estimates ice production thus constitutes $16 \%$ to $22 \%$ of the total primary production of the northern Barents Sea, depending on the extent of ice-free areas.

E. Nøst Hegseth, the Norwegian College of Fishery Science, University of Troms $\phi$, N-9037 Troms $\phi$, Norway.

\section{Introduction}

In polar regions, about 25 million $\mathrm{km}^{2}$ of the ocean surface is seasonally ice covered (Niebauer 1991). Approximately $30 \%$ of this area, or 7 to 8 million $\mathrm{km}^{2}$, is found in the Arctic (Niebauer 1991; Legendre et al. 1992). The Barents Sea, the Greenland Sea, and the Fram Strait are the main areas of the eastern part of the Arctic which are dominated by drift ice rather than by fast ice. In the Greenland Sea and Fram Strait, changes in annual ice cover are small, and ice edge position is relatively stationary in spring (between 78 and $80^{\circ} \mathrm{N}$ along $5^{\circ} \mathrm{E}$ from March to May) because opposing currents hold the ice edge in place (Niebauer 1991). An exception is the North East Water Polynya which shows large annual variability in ice cover (Wadhams 1981) and thus resembles the Barents Sea.

In the Barents Sea, as much as $75 \%$, or more than 1 million $\mathrm{km}^{2}$ may be ice-covered at maximum ice extent, and this generally includes the area north of $75^{\circ} \mathrm{N}$ (Vinje \& Kvambekk 1991). At minimum extent, this area may be ice free. Production therefore takes place both under the ice and in the water in northern Barents Sea, and ice algal production is presumably an important part of the annual primary production. However, until now no data on this production have existed. The present work presents the first data on ice algal production measured in situ, as well as measurements of the primary production north of the Polar Front during summer. An estimate of total carbon production was also partitioned into pelagic and ice-related parts. Although this is the first estimate of total carbon production from the northern Barents Sea which is based on real data, great care must be taken in making generalisations based on these data due to the limited number of stations.

\section{Materials and methods}

Production experiments were performed in situ on cruises to the Barents Sea in May 1996 and 1997 with 'Jan Mayen' (ice algal production) as well as in July and August of 1996 with 'Lance' (pelagic production). The area covered in spring 1996 was the marginal ice zone (MIZ) north to $75^{\circ} \mathrm{N}$ and east at 25 to $26^{\circ} \mathrm{E}$; in spring 1997 , the area north to $76^{\circ} 30^{\prime} \mathrm{N}$ and east at $30^{\circ} \mathrm{E}$ was covered. During 


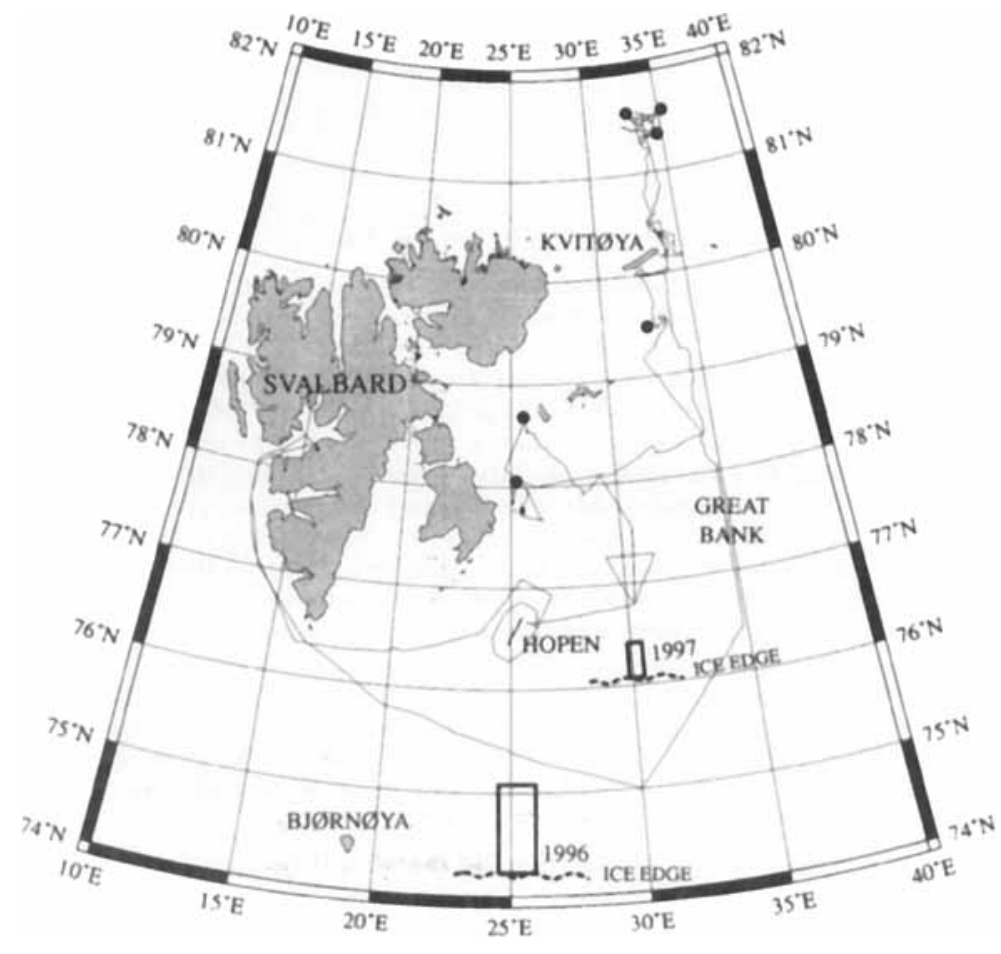

Fig. 1. Map of sampling area with cruise track for the summer cruise in 1996. Boxes represent sampling areas for ice algae in May 1996 and May 1997. Black dots indicate sampling stations. the summer of 1996, the area from the Polar Front north to $81^{\circ} 30^{\prime} \mathrm{N}$ and east from Spitsbergen to $35^{\circ} \mathrm{E}$ was investigated (Fig. 1).

Niskin water bottles (mounted on a Neill Brown CTD) were used for collecting phytoplankton samples from $0,2,5,10,20$ and $30 \mathrm{~m}$. Undiluted water samples were poured into six $50 \mathrm{ml}$ Pyrex tubes (including dark samples), $0.1 \mathrm{ml}$ of ${ }^{14} \mathrm{C}$ isotope was added, and the samples were put in the same frames used for the ice algae (see below). The frames were linked together by ropes (Helbling et al. 1997), and the mooring was either anchored to an ice floe (by sticks) in such a way that it was submerged in a lead, or it was placed free-floating in the open water. After 6 hours the mooring was retrieved, and the samples were filtered and further treated as described below. Chlorophyll samples were filtered onto GF/F filters and measured fluorometrically using methanol as the extracting solvent. Cell counting was performed under an inverted microscope. Sub-samples of 25 or $50 \mathrm{ml}$ were counted.

Underwater irradiance and natural fluorescence (upwelled radiance at $683 \mathrm{~nm}$ ) were measured with a PUV-500 Integrating irradiance meter (Biospherical Instruments). Measurements were carried out several times during each incubation period.

Ice algae were sampled under ice floes by a diver. Because ice algae in the Barents Sea grow as special sub-ice layers loosely attached to the undersurface of the ice and not inside the ice, no coring and melting step was involved in the sampling procedure. The diver used an electric suction sampler (Lønne 1988) and a cylindrical Plexiglass frame (diameter $19 \mathrm{~cm}$ ) with a serrate end. The frame was screwed tightly into the underside of the ice, and the algae layer within the frame was sucked into a net with a mesh size of $10 \mu \mathrm{m}$ inside the sampler. After collection, the algae were washed out of the net (in dim light in a tent on the ice floe) using $250-350 \mathrm{ml}$ filtered sea water from the sampling site, and the volume of the algal sample was measured in a graduated cylinder. A $50 \mathrm{ml}$ subsample was diluted with filtered sea water until no colour could be seen in the sample, usually to a total volume of $350-400 \mathrm{ml}$. Thereafter the subsample was poured into six $50 \mathrm{ml}$ Pyrex tubes (including two dark samples), $0.1 \mathrm{ml}{ }^{14} \mathrm{C}$ isotope $(5 \mu \mathrm{Ci})$ was added, and the tubes were put in an anodised aluminium frame in a horizontal position. The diver took the 
Table 1. Primary production ( $\mathrm{mg} \mathrm{C} \mathrm{m} \mathrm{m}^{-2} \mathrm{~d}^{-1}$, integrated $0-30 \mathrm{~m}$ ), average surface irradiance $\left(\mu \mathrm{mol} \mathrm{m}^{-2} \mathrm{~s}^{-1}\right.$ ) and $1 \%$ light depth of the northern Barents Sea $\left(>75^{\circ} \mathrm{N}\right)$ in summer: non-bloom, bloom and deep chlorophyll maximum situations.

\begin{tabular}{lccc}
\hline Phytoplankton condition & Primary production $\left(\mathrm{mg} \mathrm{C} \mathrm{m}^{-2} \mathrm{~d}^{-1}\right)$ & Surface irradiance $\left(\mu \mathrm{mol} \mathrm{m}^{-2} \mathrm{~s}^{-1}\right)$ & $1 \%$ light depth $(\mathrm{m})$ \\
\hline No bloom & $43-120$ & 408 & 40 \\
Bloom (moderate to high) & $187-360$ & 426 & 26 \\
Deep chlorophyll maximum & 280 & 560 & 30 \\
\hline
\end{tabular}

frame back to the sampling site where the algal layer had been removed, and it remained anchored (with ice screws) to the underside of the ice in a horizontal position for 6 hours. After incubation, the samples were filtered onto Whatman $\mathrm{GF} / \mathrm{F}$ filters, acidified with $\mathrm{HCl}$ fumes, and left overnight for drying in a vented hood. The amount of ${ }^{14} \mathrm{C}$ incorporated by the algae was determined by standard liquid scintillation techniques. In 1997 two samples from each station were collected close to each other and production was measured simultaneously for both, while in 1996 only one sample from each station was used for production measurements. Cell identification and counting were performed under a microscope equipped with phase-contrast illumination, using a PalmerMaloney counting chamber. Several hundred cells were counted of the dominating species. Underice irradiance was measured by a QSI-140 handheld integrating quantum scalar irradiance meter (Biospherical Instruments) on the sampling site where the algal layer had been removed, at the start and end of the incubation period. The production measurements were run at four of the sampling stations in 1996 and four in 1997.

\section{Results}

In May, the ice-covered areas consisted of floes of variable size, open at the outer part of the MIZ but becoming more closed further away from the edge and into the ice. In July and August, the major part of the area consisted of very open drift ice in a melting stage, except for the area north of Kvitøya $\left(80^{\circ} \mathrm{N}\right)$, where the ice cover was considerably denser.

\section{Phytoplankton}

Primary production in situ experiments were performed at six different stations, both north and south of Kvitøya (Fig. 1). Daily primary production (integrated $0-30 \mathrm{~m}$ ) was calculated for each station, and both bloom and non-bloom conditions, as well as the typical summer conditions with a deep chlorophyll maximum were encountered (Table 1). Production under nonbloom conditions varied between 40 and $120 \mathrm{mg} \mathrm{C} \mathrm{m}^{-2}$ day $^{-1}$. For blooms, it varied from 190 to $360 \mathrm{mg} \mathrm{C} \mathrm{m}^{-2}$, whereas the deep phytoplankton layers exhibited daily production rates of $280 \mathrm{mg} \mathrm{C} \mathrm{m}^{-2}$. Under-water irradiance (Table 1) and natural fluorescence were calculated as an average of the measurements obtained during the

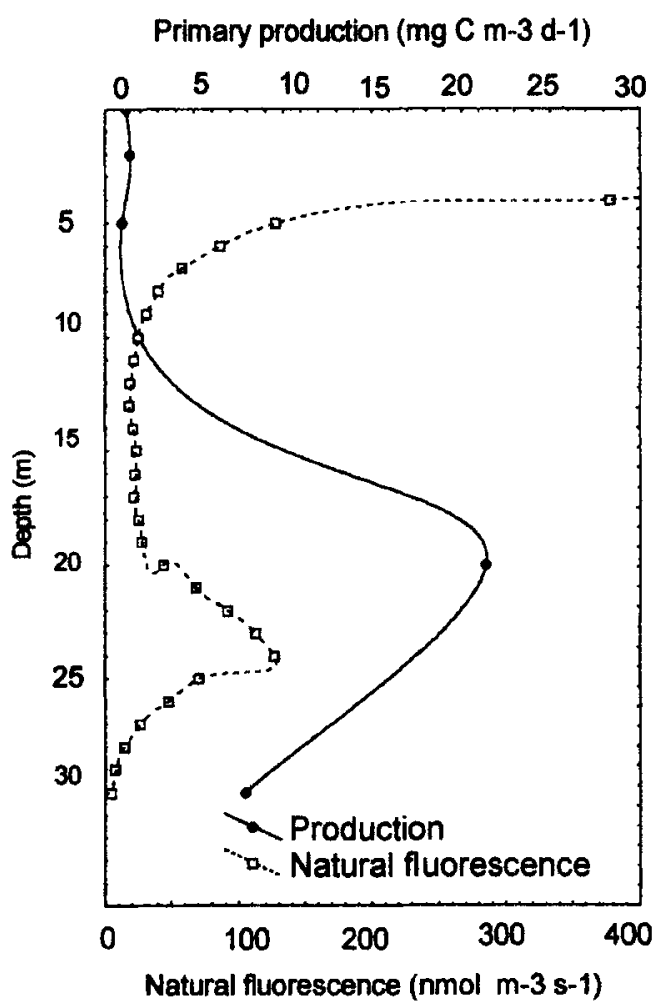

Fig. 2. Distribution of primary production in the water column of an open water station in summer of 1996 (August 10). Profiles represent in situ measurements of ${ }^{14} \mathrm{C}$ uptake ( $\mathrm{mg} \mathrm{C} \mathrm{m} \mathrm{C}^{-3} \mathrm{~d}^{-1}$ ) and natural fluorescence $\left(\mathrm{nmol} \mathrm{m} \mathrm{s}^{-3} \mathrm{~s}^{-1}\right.$ ). 


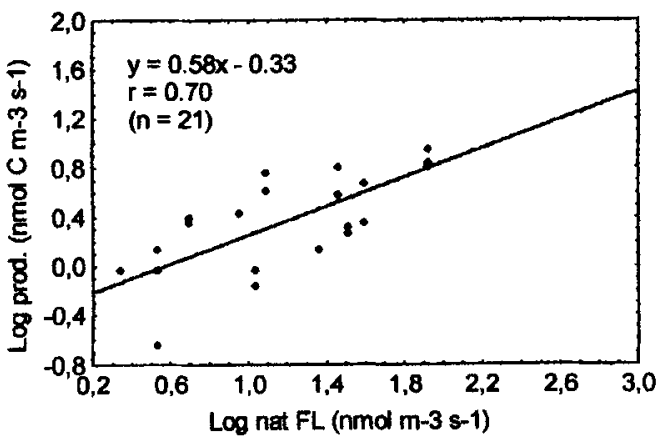

Fig. 3. Plot of measured production ( $\mathrm{nmol} \mathrm{C} \mathrm{m} \mathrm{m}^{-3} \mathrm{~s}^{-1}$ ) vs. natural fluorescence (nmol m $\mathrm{m}^{-3} \mathrm{~s}^{-1}$ ) for the primary production experiments in the summer of 1996 in the northern Barents Sea. Data are taken from 6 to $30 \mathrm{~m}$ depth.

incubation period. For further calculations of the relationship between natural fluorescence and in situ primary production, data from below $6 \mathrm{~m}$ depth were used, as natural fluorescence can be measured only when the red wavelengths of the visible light are totally absorbed.

The profiles of the in situ measurements of primary production were consistent with profiles of the average natural fluorescence (FL) below $6 \mathrm{~m}$ from the same stations (Fig. 2). The FL data from each station were thereafter correlated with in situ primary production values (Fig. 3). A good correlation was found, described by the following equation:

$\log$ prod. $\left(\mathrm{nmol} \mathrm{C} \mathrm{m}^{-3} \mathrm{~s}^{-1}\right)=\{\log$ natural FL $\left.\left(\mathrm{nmol} \mathrm{m} \mathrm{m}^{-3} \mathrm{~s}^{-1}\right)\right\} \mathrm{x}-0.33, \mathrm{r}=0.70(\mathrm{n}=21)$

Production is given in $\mathrm{nmol} \mathrm{C} \mathrm{m}^{-3} \mathrm{~s}^{-1}$ to match the natural fluorescence data measured in nmol photons $\mathrm{m}^{-3} \mathrm{~s}^{-1}$.

The profiles of primary production were, however, not always consistent with the profiles of chlorophyll; they exhibited a mismatch between biomass maximum and production maximum. Production maximum was generally found above the chlorophyll maximum, and the surface production was enhanced relative to the biomass (Fig. 4).

The species composition differed over the study area, but the general trend was a predominance of small flagellates, including dinoflagellates (autotrophs and heterotrophs) under non-bloom conditions, diatom predominance in blooms, and a mixture of diatoms (with resting spores) and Phaeocystis pouchetii in deep chlorophyll maximum. Biologically, the area was divided into several sub-areas based on the growth stages of the phytoplankton populations, which was judged by the chlorophyll distribution and the species composition. The southern part of the investigated area, south of Kvitøya, was dominated by a deep chlorophyll maximum made up of Phaeocystis in the Polar Front area. Further north, phytoplankton was particularly scarce in the eastern part over the Great Bank (Fig. 1) and dominated by small dinoflagellates and other flagellates. To the west, a deep chlorophyll maximum made up of Chaetoceros socialis with resting spores, Phaeocystis, and small flagellates predominated. Around Kvitøya, bloom conditions were found which were characterised by a high biomass in the upper layers and predominated by diatoms such as Thalassiosira ( $T$. antarctica var. borealis, $T$. bioculata, $T$. nordenskioeldii) and Chaetoceros (C. socialis, C. fragilis). In the northern part,

Table 2. Ice thickness $(\mathrm{m})$, snow depth $(\mathrm{m})$, under-ice irradiance (average for incubation period, $\mu \mathrm{mol} \mathrm{m}^{-2} \mathrm{~s}^{-1}$ ) and daily ice algal production $\left(\mathrm{mg} \mathrm{C} \mathrm{m}^{-2}\right.$ ) of sampling sites in the northern Barents Sea in May 1996 and May 1997.

\begin{tabular}{lccccc}
\hline Date & $\begin{array}{c}\text { Ice } \\
\text { thickness }\end{array}$ & $\begin{array}{c}\text { Snow } \\
\text { depth }\end{array}$ & Irradiance & Production \\
\hline May 1996 & $0.40-0.45$ & $20-30$ & 53 & 9.50 & $(\mathrm{n}=1)$ \\
& $1.00-1.20$ & $10-20$ & $27(11-43)$ & $8.50-25$ & $(\mathrm{n}=2)$ \\
& 2.00 & $50-60$ & 0.7 & 0.16 & $(\mathrm{n}=1)$ \\
May 1997 & & & 48 & $0.16-25($ av. 10.8) & Day (n=2) \\
& $0.20-0.30$ & $2-5$ & 19 & 0.10 & Night (n=2) \\
& $0.20-0.30$ & $10-20$ & $30(10-48)$ & $5.0-52$ & Day (n=6) \\
& $0.80-0.90$ & $10-20$ & 7.80 & Night (n=2) \\
& $0.80-0.90$ & & & $3.10-52$ & Day (av. 16.0) \\
& & & & $0.70-1.80$ & Night (av. 1.30) \\
\hline
\end{tabular}



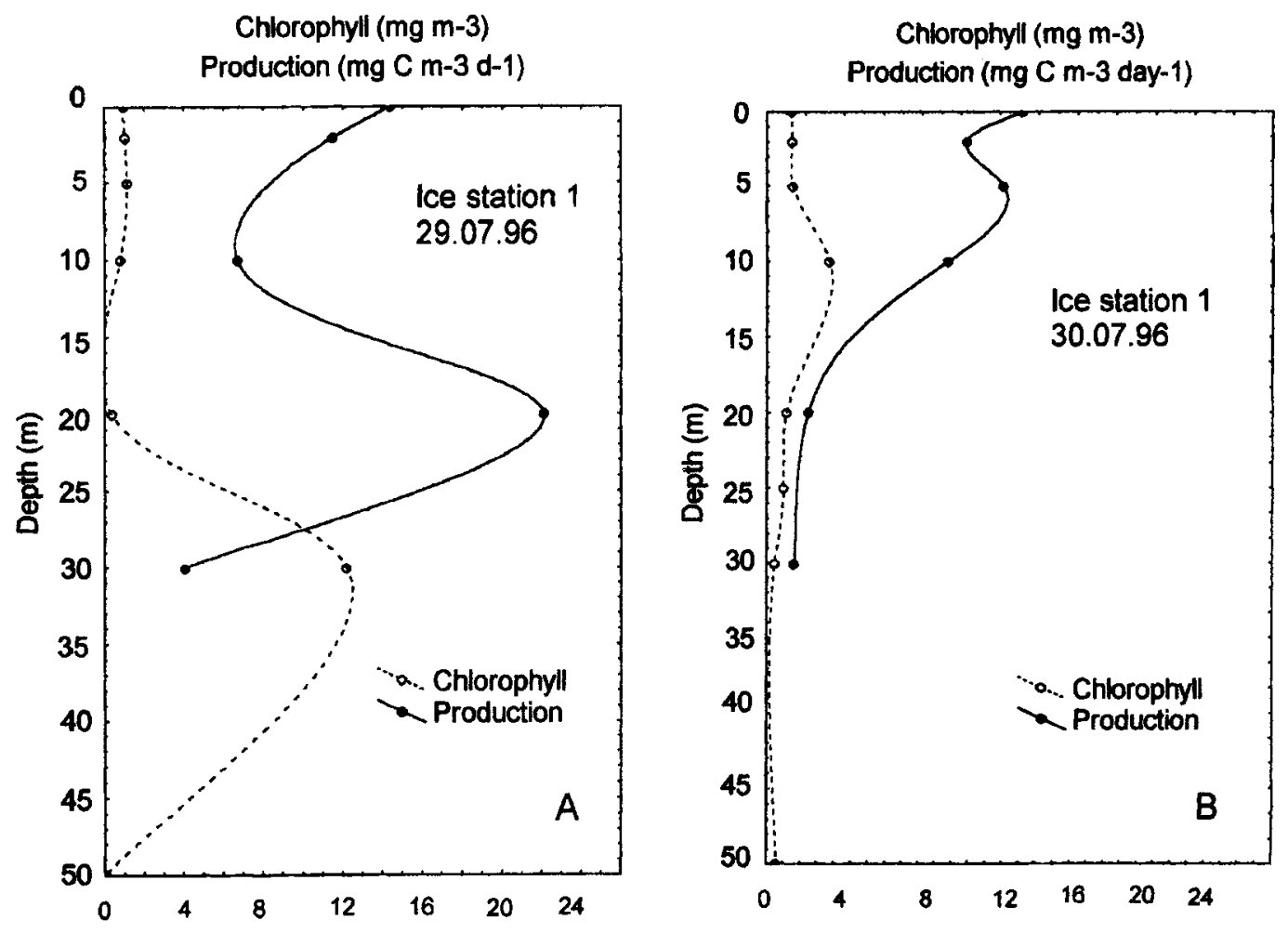

Fig. 4. Distribution of chlorophyll $\left(\mathrm{mg} \mathrm{m}^{-3}\right)$ and primary production $\left(\mathrm{mg} \mathrm{C} \mathrm{m}^{-3} \mathrm{~d}^{-1}\right)$ in the water masses of the northernmost ice station in summer of 1996 (July $29 \& 30$ ).

blooms were occasionally found which were predominated either by $T$. bioculata and $T$. nordenskioeldii, or by $C$. socialis.

\section{Ice algae}

The ice thickness of the sampling sites in May 1996 was either in the range of 40 to $50 \mathrm{~cm}$ or greater than $1 \mathrm{~m}$ (Table 2). Snow depths were 10 to $30 \mathrm{~cm}$, except for one station with a heavy snow layer $(50 \mathrm{~cm})$ and correspondingly thick ice of $2 \mathrm{~m}$. In May 1997, most of the sampling sites had an ice thickness of $80 \mathrm{~cm}$ (one sample was taken below $30 \mathrm{~cm}$ of ice). Snow depths were 10 to $20 \mathrm{~cm}$ (Table 2) except for the station with the thin ice where snow depth was only $2-3 \mathrm{~cm}$. Irradiance during incubation periods varied, depending on ice and snow thickness and weather conditions. At daytime, the maximum irradiance measured was $65 \mu \mathrm{mol} \mathrm{m} \mathrm{m}^{-2} \mathrm{~s}^{-1}$ (average for incubation period $48 \mu \mathrm{mol} \mathrm{m}^{-2} \mathrm{~s}^{-1}$ ), and the minimum about $10 \mu \mathrm{mol} \mathrm{m}^{-2} \mathrm{~s}^{-1}$, except for the one thick floe with under-ice irradiance as low as
$0.7 \mu \mathrm{mol} \mathrm{m}^{-2} \mathrm{~s}^{-1}$. Night values were in the range of 7 to $19 \mu \mathrm{mol} \mathrm{m}^{-2} \mathrm{~s}^{-1}$ (Table 2). The highest values (day and night, same station) were measured below the thinnest ice and snow cover. In both years the weather conditions were generally cloudy. The cruises took place during the midnight sun season, hence the nights were often fairly bright although there was no direct sunlight.

Production experiments were run only at daytime in May 1996 (four stations), but in 1997 on four days and two nights (four stations). The results of the measurements are presented both as carbon production per day and night (Table 2) and as annual production (Table 4). There is light for 24 hours during May, but irradiance is substantially lower during night. Accordingly, night production (6 hours) was much lower, on average $8 \%$ of day production (18 hours). However, night production is included in the calculations of annual production, where the productive period is set to 100 days and 60 nights. These calculations might be too low as growth probably starts 
as early as March (Hegseth 1992) and may continue well into July; however, to compensate for this, the maximum production measured was used to calculate the amount of ice algal carbon produced during a year.

Daily production rates were found to be highly variable, both between stations and between years, average values being 50\% higher in 1997 than in 1996 (Table 2). The highest rate encountered was $52 \mathrm{mg} \mathrm{C} \mathrm{m}^{-2}$, and the lowest was $0.16 \mathrm{mg} \mathrm{C} \mathrm{m}^{-2}$. The latter was measured below the thickest ice and snow cover. This gave a maximum annual production of $5.2 \mathrm{~g} \mathrm{C} \mathrm{m}^{-2}$. Night production was, on average, $1.30 \mathrm{mg} \mathrm{C} \mathrm{m}^{-2}$, and annually, it was $0.075 \mathrm{~g} \mathrm{C} \mathrm{m}^{-2}$.

All the samples were predominated by diatoms, mainly pennate species. This is the usual composition of ice algal assemblages in the Barents Sea (Hegseth 1992). Species variability was high, however, and in 1997, the haptophycean Phaeocystis pouchetii contributed significantly to the numerical count but not to the biomass because of its small cells. In this particular year, the pelagic blooms were completely predominated by Phaeocystis, which was found everywhere in water, below ice, and on ice. In 1996, the predominating diatoms were Nitzschia promare, Fragilariopsis oceanica, and Pseudogomphonema arctica, while in 1997, N. frigida, N. promare, Fossula arctica, and Synedropsis hyperborea were the most numerous, with $N$. frigida being the predominating species.

\section{Discussion}

The Barents Sea consists of at least eight water masses, the main ones being the Atlantic Water south of the Polar Front $\left(74\right.$ to $\left.76^{\circ} \mathrm{N}\right)$ and the Arctic Water north of the Front (Loeng 1991). In the Front area, these water masses mix into the Polar Front Water. During winter, drift ice usually covers the Arctic Water.

The majority of ice in the Barents Sea is firstyear ice, formed locally. During winter, the Barents Sea exports ice (Vinje 1985). Occasionally, there may be some influx of multi-year ice from the Arctic Ocean through the passages east of Svalbard, amounting to a maximum of $0.8 \%$ to $1.3 \%$ of the ice-covered area.

Maximum ice cover is found in March and
April, and minimum is found in August and September (Vinje 1985). Freezing normally starts in mid-September and proceeds rapidly so that the ice cover may be close to maximum extent by the end of the year. Correspondingly, melting proceeds slowly from April or May to June but then proceeds rapidly from June to August (Loeng 1979). Since the turn of the century, there has been a $40 \%$ reduction in the ice-covered area at the end of the melting season, but no reduction in winter maximum extension. This indicates an ongoing reduction in ice thickness, and in the last 25 years there has been an increasing number of ice-free summers (Vinje \& Kvambekk 1991).

In the Kvitøya-Nordaustlandet Strait, ice drift is controlled by the wind because of the strait's generally weak net water currents (about $2 \mathrm{~cm} \mathrm{~s}^{-1}$, directed north-westwards) (Vinje 1985). This is in contrast to the situation in the Fram Strait, where $70 \%$ to $80 \%$ of the ice drift can be ascribed to the persisting south-bound Transpolar Current (Vinje \& Finnekåsa 1986). Ice velocity amounts to $1 \%$ to $2 \%$ of the geostrophic wind speed, and in addition tides cause periodic movements of the ice cover (Vinje \& Kvambekk 1991). As a result, the ice cover is more or less constantly moving, with ridging, floes breaking up, and leads opening. In winter, up to $60 \%$ of the leads are less than $50 \mathrm{~m}$ wide $(40 \%$ to $45 \%$ for the rest of the year) and occur in the outer 10 to $50 \mathrm{~km}$ of MIZ (Vinje 1985). Winds from north and east are predominant, pushing the ice cover to the southwest. This causes a diffuse ice border with a broad MIZ. Opposing winds, however, push the ice northwards, creating a very sharp ice edge.

The thickness of the ice cover, on average, has been calculated to be $0.95 \mathrm{~m}$ at $75^{\circ} \mathrm{N}$ and $1.70 \mathrm{~m}$ at $80^{\circ} \mathrm{N}$, based on an observed relationship between ice thickness and accumulated degreedays (Vinje \& Kvambekk 1991). Snow cover depth in the Barents Sea is 20 to $30 \mathrm{~cm}$ on firstyear ice in winter and spring; this decreases to $10 \mathrm{~cm}$ in early summer. On multi-year ice in autumn, the snow cover may be up to $10 \mathrm{~cm}$, but is usually less (Hegseth 1992).

\section{Pelagic production}

Phytoplankton biomass is low in ice-covered areas in the spring and summer (Hegseth 1992). The ice cover acts as a lid, keeping light away from algae in the water masses. The pelagic growth season in the northern Barents Sea there- 
Table 3. Annual primary production $\left(\mathrm{g} \mathrm{C} \mathrm{m}^{-2}\right)$ of the northern Barents Sea, measurements and model estimates.

\begin{tabular}{lcll}
\hline Area & $\mathrm{g} \mathrm{C} \mathrm{m}^{-2}$ & \multicolumn{1}{c}{ Data based on } & \multicolumn{1}{c}{ References } \\
\hline Northern Barents Sea & 49 & Nitrate consumed & Rey et al. 1987 \\
Northern Barents Sea & $25-40$ & Model estimates & Slagstad \& Støle-Hansen 1991 \\
Northern Barents Sea & $5-29$ & Model estimates: new prod. & Wassmann \& Slagstad 1993 \\
& 40 & Model estimates: total prod. & Wassmann \& Slagstad 1993 \\
Polar Front - Kvitøya & $25-30$ & In situ ${ }^{14} \mathrm{C}$ measurements & This work \\
North of Kvitøya & $12-15$ & In situ ${ }^{14} \mathrm{C}$ measurements & This work \\
\hline
\end{tabular}

fore starts when the ice cover melts, and production is mainly confined to the MIZ. Leads may offer an opportunity for enhanced production, but a constantly moving ice cover prevents long-lived leads from occurring. In mid-May, well after melting has started, pronounced ice-edge blooms may occur, and biomass values up to 500 to $600 \mathrm{mg}$ chlorophyll $\mathrm{m}^{-2}$ have been found in the upper $50 \mathrm{~m}$ (Hegseth 1992). In very cold years, ice cover may extend south of the Polar Front, and then melting may start earlier. Ice-edge blooms have been recorded in mid-April, with the biomass reaching $900 \mathrm{mg}$ chlorophyll $\mathrm{m}^{-2}$ for such blooms in ice-edge areas overlaying Atlantic Water (Hegseth 1992). Consequently, pelagic production starts earliest in the coldest years.

The annual pelagic production is different north and south of the Polar Front due to different physical conditions, ice cover being the most important factor. Calculations of total primary production have been performed for the southern part of the Barents Sea by both Norwegian and Russian scientists. Data are either based on production measurements by uptake of ${ }^{14} \mathrm{C}$ (Rey et al. 1987; Rey 1993; Savinov 1992) or on calculations made from nitrate consumption in the area (Rey et al. 1987; Rey 1993). In addition, production has been estimated from model simulations (Slagstad \& Støle-Hansen 1991; Wassmann \& Slagstad 1993). Data based on nitrate consumption fit well with the new production values from the models, and the most recent calculations of production from ${ }^{14} \mathrm{C}$ uptake measurements (Rey 1993) are in the same range as the modelled total production. The Russian data give only half the Norwegian values if calculated from the average figures presented in Savinov (1992, table 10), while maximum figures give comparable values. Thus, in the southern Barents Sea, models seem to provide annual production values in good agreement with measurements.

In the northern Barents Sea, however, insuffi- cient measurements have been made to allow calculation of the annual production. The only figure available, except for model estimates, has been that of Rey et al. (1987), which is based on nitrate consumption in the depth layer of 0 to $100 \mathrm{~m}$. The figure is twice the value of average model estimates of new production (Wassmann \& Slagstad 1993) and also higher than estimates of total production for the Barents Sea north to $80^{\circ} \mathrm{N}$ (20-40 $\mathrm{g} \mathrm{C} \mathrm{m}^{-2}$ depending on latitude, (Slagstad \& Støle-Hansen 1991; Wassmann \& Slagstad 1993). In the models, a major part of the production is assumed to be new production manifested as ice edge blooms. The blooms are further assumed to follow the retreating ice edge all summer, and blooms recorded in MIZ in beginning of September show that this may occur, both in the Barents Sea (Hegseth 1997) and in the waters northwest of Spitsbergen (Heimdal 1983). The total annual production (Table 3) in the northern Barents Sea is estimated from models to reach a maximum of $40 \mathrm{~g} \mathrm{C} \mathrm{m}^{-2}$ (Slagstad \& Støle-Hansen 1991) and is calculated from nitrate consumption figures to be $48.8 \mathrm{~g} \mathrm{C} \mathrm{m}^{-2}$ (Rey et al. 1987).

The present investigation shows the northern part of the Barents Sea as a patchwork of productive areas in summer. During the summer cruise in 1996, there was no definite ice edge because melting was taking place throughout the area from the Polar Front to $81^{\circ} \mathrm{N}$. South of Kvitøya, scattered ice floes of variable size predominated and no typical ice edge blooms were encountered. However, local areas exhibited blooming conditions that were not related to an ice edge. One of those areas was the open water around Kvitøya, a polynya which opens up early in the season, as verified from ice maps (in 1996, first seen open on 20 May). Phytoplankton populations indicated spring bloom condition with spring diatom species and a biomass maximum in the surface layers. This is probably an ongoing 
condition formed by the last branch of Atlantic Water which flows northwards along the western coast of Svalbard, turns east on the northern side of the island, and finally surfaces at Kvitøya (Pfirman et al. 1994; Falk-Petersen et al. unpubl.).

The other area with phytoplankton blooms was found north of Kvitøya. Ice cover was denser and the ice thicker than was the case further south, and production was occurring in the leads. Spring conditions, as in the Kvitøya area, were encountered (spring diatom species, biomass concentrated in upper layers), and the developmental stages of the blooms were probably dependent on the previous open period of the leads. Additionally, the ship drifted over a subsurface bloom trapped in a core-like water mass which exhibited high production rates (Fig. 4A) and different phytoplankton populations (Hegseth, unpubl.).

In the areas south of Kvitøya, blooms had apparently already come and gone since phytoplankton populations were in a late developmental stage, a deep biomass maximum predominated by Phaeocystis and diatoms with resting spores. A very cold water mass dominating the Great Bank probably caused a local low-productive area in an otherwise productive region.

It seems appropriate that the northern Barents Sea be treated as two (at a minimum) sub-areas, the first from the Polar Front to Kvitøya and the second north of Kvitøya. The latter is considered separately because it may not be open every year and in addition it also has a shorter productive period. As a first approximation, based on our relatively few production values, estimates of annual production have been performed from daily production rates of the in situ experiments. Our measurements cover the upper $30 \mathrm{~m}$, corresponding roughly to the depth of the euphotic zone (1\% light depth, Table 1). Values are in good agreement with previous measurements from the northern Barents Sea (Eilertsen et al. 1989b) and the Polar Front area (Eilertsen et al. 1989a; Hansen et al. 1989) in summer. All of these investigations represent mostly post-bloom conditions with a deep chlorophyll maximum. We therefore consider our measurements as representative for such conditions in the northern Barents Sea. Low production (no bloom) has earlier been encountered in the Polar Front area, with corresponding production values as in the present investigation (Eilertsen et al. 1989a). Spring bloom conditions have not, to my knowledge, been recorded earlier this far north. As there are no data with which we can compare the present investigations, we can only assume that the values are representative for the conditions they cover.

The following assumptions were made to estimate annual production: (1) in the high north there are 2 weeks of low production, 4 weeks of moderate production, and 2 weeks of bloom; (2) further south, in the Kvitøya area, there are 4 weeks of low production and 12 weeks of bloom (the polynya stays open 4 months); and (3) south of Kvitøya there are 4 weeks of very low production, 6 weeks of medium production, and 4 weeks of high production (bloom). These assumptions disregard the low production of the Great Bank because this production represent a periodic situation. In summary, we arrive at an annual production of 12 to $15 \mathrm{~g} \mathrm{C} \mathrm{m}^{-2}$ in the high north and 25 to $30 \mathrm{~g} \mathrm{C} \mathrm{m}^{-2}$ further south (Table 3 ). The figures may, however, be too low, particularly for the areas south of Kvitøya since they do not include measurements from a typical spring bloom condition in MIZ. High spring bloom production rates, although short-lived, have been reported from the southern Barents Sea (Rey et al. 1987). During our cruise, weather conditions were probably sub-optimal for primary production, with fog 25 out of 28 days and low light intensities (Table 1). These are, however, normal summer conditions for the Barents Sea, particularly in the northern part. Even so, the previous model estimates are in good agreement with the calculations based on the in situ measurements for the northern Barents Sea. The number of stations in our investigations are limited and great care must be taken in generalising from these data. However, our calculation for annual pelagic production north of Kvitøya corresponds well with recent estimates of primary production in the Arctic Ocean from dissolved oxygen (Pomeroy 1997) and new measurements of pelagic and ice algal production from the same ocean $\left(15 \mathrm{~g} \mathrm{C} \mathrm{m}^{-2}\right.$ year $^{-1}$, Gosselin et al. 1997). By including ice algal production in our estimates, the northern rim of the Barents Sea would exhibit production values slightly higher than those of the Arctic Ocean, which seems reasonable.

Some of the sub-areas only have natural fluorescence profiles and no experimentally measured production. The relationship shown in Equation 1 strongly suggests that there is a close relationship between natural fluorescence and the measured primary production, as has previously been shown for tropical and temperate areas 
Table 4. Estimates of the annual production of arctic ice algae $\left(\mathrm{g} \mathrm{C} \mathrm{m}^{-2}\right)$.

\begin{tabular}{llcl}
\hline Area & Type of ice & $\mathrm{g} \mathrm{C} \mathrm{m}^{-2}$ & References \\
\hline Davis Strait & Fast ice & $0.15^{\mathrm{b}}$ & Anderson 1977 \\
Labrador Coast & Pack ice & $4.4^{\mathrm{a}}$ & Irwin 1990 \\
Resolute, Barrow & Fast ice & $1.8^{\mathrm{b}}, 14^{\mathrm{a}}$ & Smith \& Herman 1991 \\
Strait & & $1.1-23^{\mathrm{a}}$ & Smith et al. 1988 \\
& $5.0^{\mathrm{a}}$ & Bergman et al. 1991 \\
Beaufort Sea, & Fast ice & $0.7^{\mathrm{b}}, 5.0^{\mathrm{a}}$ & Horner \& Schrader 1982, Alexander 1974 \\
Point Barrow & & $0.3-8.3^{\mathrm{b}}$ & Clasby et al. 1973 \\
Bering Sea & Pack ice & $0.2-1.5$ & Alexander \& Chapman 1981 \\
Barents Sea & Fast ice & $0.2-0.4^{\mathrm{a}}$ & McRoy \& Goering 1974 \\
\hline
\end{tabular}

\footnotetext{
${ }^{a}$ Incubator.

${ }^{\mathrm{b}}$ In situ.

${ }^{\mathrm{c}}$ Estimated, based on $18 \mathrm{~h}$ day, 60 days growth period.

${ }^{d}$ Estimated, based on 90 days growth period.
}

(Kiefer et al. 1989; Chamberlin et al. 1990). However, no data have yet been published from polar areas comparing the two production estimates, and the number of experiments performed during the present investigation is probably too low to ensure calculation of a reliable relationship. There are several other unsolved problems as well, one being the surface values. Since natural fluorescence cannot be measured in the upper $6 \mathrm{~m}$, that part of the water column where maximum biomass and/or production are/is often found in these areas, particularly during phytoplankton bloom conditions (Fig. 4), production measured solely by a sensor may lose the upper layer production. Although a mismatch between chlorophyll distribution and production is seen here, this is not always the case, as in the late growth state with a deep chlorophyll maximum corresponding to a deep production peak. However, production may be underestimated if chlorophyll distribution is used as a guideline for production patterns. Species composition and high light conditions may also interfere with the relationship (Sakshaug et al. 1997), so at present, natural fluorescence measurements can rather be considered as valuable indicators of primary production distribution.

\section{Ice algal production}

Already by the end of February, algal cells have been found above the Svalbard Bank on the underside of the ice along with silt and clay. In mid-April, a distinct brown layer is visible, indicating that growth must have been occurring for some time (Hegseth 1992). Ice flora does not grow inside ice, but grows concentrated in mats on the underside of the ice. When melting starts, after a small increase in the water temperature, the ice algal layer loses its attachment to the ice underside and disintegrates in the water column, probably sinking to the bottom. True ice algal species do not form blooms in open water.

In September, remnants of the previous summer's ice flora are found far north $\left(81^{\circ} \mathrm{N}\right)$ in nonmelted ice. In sheltered habitats in multi-year ice, such as on upper, more or less horizontal, sides of floes in pressure ridges and rafted ice, algae are found in early October. By then, however, the cells have gone into a resting stage (recognised by a condensed cell content), clearly indicating that the growth season terminates when the annual ice cover melts (Hegseth 1992). This occurred in the summer of 1996 when almost all ice flora had disappeared by the time we arrived. The productive season for the ice algae thus lasts for a maximum of 4 months in the northern part of the Barents Sea.

Although this is the first time that in situ ice algal production has been measured in the Barents Sea, photosynthetic parameters have been measured earlier in a deck incubator (Johnsen \& Hegseth 1991). The highest production found for the ice flora in the northern Barents Sea is comparable to production estimates from other arctic areas (Table 4). These figures are among the highest found in the Arctic, indicating that the sub-ice algal mats of the Barents Sea are highly productive communities, although the biomass may not be particularly high. This points to a system with high turnover rates. 
Table 5. Estimates of total and partitioned carbon production in the northern Barents Sea. Units are: carbon production $\left(\mathrm{g} \mathrm{C} \mathrm{m}^{-2}\right.$ year $\left.^{-1}\right)$, area $\left(10^{12} \mathrm{~m}^{2}\right)$, annual production and total production $\left(10^{12} \mathrm{~g} \mathrm{C}_{\text {year }}{ }^{-1}\right)$.

\begin{tabular}{lcccc}
\hline Biotope & Carbon prod. & Area & Annual prod. & Total prod. \\
\hline Ice & 5.3 & 0.8 & 4.2 & 18.0 \\
Water, south of Kvitøya & 30 & 0.6 & 3.0 & 25.2 \\
Water, north of Kvitøya & 15 & 0.2 & & \\
Northern Barents Sea & & & & \\
\hline
\end{tabular}

\section{Total and partitioned primary production}

The total amount of organic carbon produced in the northern Barents Sea was calculated from real measurements and not from models. 0.8 million $\mathrm{km}^{2}$ was used as an average maximum for the icecovered area, based on ice maps from a ten-year period (Vinje 1985). Of this roughly $3 / 4$ (0.6 mill $\mathrm{km}^{2}$ ) is situated south of Kvitøya and $1 / 4$ $\left(0.2 \mathrm{~km}^{2}\right)$ north of it. The polynya around Kvitøya is included in the southern area.

The calculations (Table 5) show that ice algal production makes up between $16 \%$ and $22 \%$ of the total production in the northern Barents Sea, depending on whether the area north of Kvitøya is open. For the Arctic as a whole, ice-related production has been estimated by Legendre and others (1992) to be either $25 \%$ or $35 \%$ of open water production, depending on whether the latter includes offshore production or only shelf production. However, these authors used a value for ice production that was twice that found for the Barents Sea ice flora. By using the same value of $5 \mathrm{~g} \mathrm{C} \mathrm{m}^{-2}$ year $^{-1}$, the estimate of the total arctic ice algal production is reduced to $50 \%$, now representing $15 \%$ to $22 \%$ of open water production, which is comparable to the Barents Sea level.

If the ongoing reduction in ice cover thickness proceeds, it will most certainly have an effect on ice production, which is found to be light limited (Hegseth 1992). The ice algal production in seasonally ice-covered areas is of great importance to high arctic ecosystems, and the need for more measurements and better quantification of both ice-related and pelagic production is paramount in view of the importance of the Arctic in the global carbon cycle.

Acknowledgements. - The author wishes to thank colleagues and crews on the cruises for all assistance during sampling of ice algae and phytoplankton. Thanks are especially due to $\mathrm{B}$. Seim for performing all the diving and to C. Hellum von Quillfeldt and Y. Okolodkov for cell counting. These investigations are part of the Pilot Arctic Ocean Project, funded by the Norwegian
Research Council, and the Norwegian Polar Institute's ICEBAR program.

\section{References}

Alexander, V. 1974: Primary productivity regimes of the nearshore Beaufort Sea, with references to the potential role of ice biota. Pp. 609-635 in Reed, J. C. \& Sater, J. E. (eds.): The coast and shelf of the Beaufort Sea. Proceedings of the Symposium on 'Beaufort Sea coast and shelf research'. Arctic Institute of North America, Arlington.

Alexander, V. \& Chapman, T. 1981: The role of epontic algal communities in Bering Sea ice. Pp. 773-780 in Hood, D. W. \& Calder, J. A. (eds.): The Eastern Bering Sea Shelf: Oceanography and resources. University of Washington.

Anderson, O. G. N. 1977: Primary production associated with sea ice at Godhavn, Disco, West Greenland. Ophelia 16, 205-220.

Bergmann, M. A., Welch. H. E., Butler-Walker, J. E. \& Siferd, T. D. 1991. Ice algal photosynthesis at Resolute and Saqvaqjuac in the Canadian Arctic. J. Mar. Syst. 2, 43-52.

Chamberlin, W. S., Booth, C. R., Kiefer, D. A., Morrow, J. H. \& Murphy, R. C. 1990: Evidence for a simple relationship between natural fluorescence, photosynthesis, and chlorophyll in the sea. Deep-Sea Res. 37, 951-973.

Clasby, R. C., Horner, R. \& Alexander, V. 1973: An in situ method for measuring primary productivity of Arctic sea ice algae. J. Fish. Res. Board Can. 30, 835-838.

Eilertsen, H. C., Tande, K. S. \& Hegseth, E. N. 1989a: Potential of herbivorous copepods for regulating the spring phytoplankton bloom in the Barents Sea. Rapp. P.-v. Réun. Cons. int. Explor. Mer 188, 154-163.

Eilertsen, H. C., Tande, K. S. \& Taasen, J. P. 1989b: Vertical distributions of primary production and grazing by Calanus glacialis Jaschnov and $C$. hyperboreus Kroyer in Arctic Waters (Barents Sea). Polar Biol. 9, 253-260.

Gosselin, M., Levasseur, M., Wheeler, P. A., Horner, R. A. \& Booth, B. C. 1997: New measurements of phytoplankton and ice algal production in the Arctic Ocean. Deep-Sea Res. II, 44, 1623-1644.

Hansen, B., Berggren, U. C., Tande, K. S. \& Eilertsen, H. C. 1989: Post-bloom grazing by Calanus glacialis, C. finmarchicus and $C$. liyperboreus in the region of the Polar Front, Barents Sea. Mar. Biol. 104, 5-14.

Hegseth, E. N. 1992: Sub-ice algal assemblages of the Barents Sea: Species composition, chemical composition, and growth rates. Polar Biol. 12, 485-496.

Hegseth, E. N. 1997: Phytoplankton of the Barents Sea - the end of a growth season. Polar Biol. 17, 235-241. 
Heimdal, B. R. 1983: Phytoplankton and nutrients in the waters north-west of Spitsbergen in the autumn of 1979. J. Plankton Res. 5, 901-918.

Helbling, E. W., Eilertsen, H. C., Villafane, V. E. \& HolmHansen, O. 1997: Effects of ultraviolet radiation on postbloom phytoplankton populations in Kvalsund, North Norway. J. Photochem. Photobiol. 33, 255-259.

Horner, R. \& Schrader, G. C. 1982: Relative contribution of ice algae, phytoplankton, and benthic microalgae to primary production in nearshore regions of the Beaufort Sea. Arctic $35,485-503$.

Irwin, B. D. 1990: Primary production of ice algae on a seasonally-ice-covered, continental shelf. Polar Biol. 10 , 247-254.

Johnsen, G. \& Hegseth, E. N. 1991: Photoadaptation of sea-ice microalgae in the Barents Sea. Polar Biol. 11, 179-184.

Kiefer, D. A., Chamberlin, W. S. \& Booth, C. R. 1989: Natural fluorescence of chlorophyll $a$ : relationship to photosynthesis and chlorophyll concentration in the western South Pacific gyre. Limnol. Oceanogr. 34, 868-881.

Legendre, L., Ackley, S. F., Dieckmann, G. S., Gulliksen, B., Homer, R., Hoshiai, T., Melnikov, I. A., Reeburgh, W. S., Spindler, M. \& Sullivan, C. W. 1992: Ecology of sea ice biota. 2. Global significance. Polar Biol. 12, 429-444.

Loeng. H. 1979: A review of the sea ice conditions of the Barents Sea and the area west of Spitsbergen. Fisken Hav 2, 29-75 (in Norwegian, summary in English).

Loeng. H. 1991: Features of the physical oceanographic conditions of the Barents Sea. Polar Res. 10, 5-18.

Lømne, O. J. 1988: A diver-operated electric suction sampler for sympagic (= under-ice) invertebrates. Polar Res. 6, 135-136.

McRoy C. P. \& Goering J. J. 1974: The influence of ice on the primary productivity of the Bering Sea. Pp. 403-421 in Hood, D. W. \& Kelley, E. J. (eds.): Oceanography of the Bering Sea. Inst. Mar. Sci. Pub. No. 2. University of Alaska, Fairbanks.

Niebauer, H. J. 1991: Bio-physical oceanographic interactions at the edge of the Arctic ice pack. J. Mar. Syst. 2, 209-232.

Pfirman, S. L., Bauch, D. \& Gammelsrød, T. 1994: The northern Barents Sea: water mass distribution and modification. Pp. 77-93 in Johannessen, O. M., Muench, R. D. \& Overland, J. E. (eds.): The polar oceans and their role in shaping the global environment. Geophys. Monogr. 85.
Pomeroy, L. R. 1997: Primary production in the Arctic Ocean estimated from dissolved oxygen. J. Mar. Syst. 10, 1-8.

Rey, F. 1993: Phytoplankton and its primary production in the Northern Barents Sea. Fisken Hav. 10, 1-39 (in Norwegian, summary in English).

Rey, F.. Skjoldal, H. R. \& Slagstad, D. 1987: Primary production in relation to climatic changes in the Barents Sea. Pp. 29-46 in Loeng, $H$. (ed.): The effect of oceanographic conditions on distribution and population dynamics of commercial fish stocks in the Barents Sea. Institute of Marine Research, Bergen, Norway.

Sakshaug, E., Bricaud, A., Dandonneau, Y., Falkowski, P. G., Kiefer, D. A., Legendre L., Morel, A., Parslow, J. \& Takahashi, M. 1997: Parameters of photosynthesis: definitions, theory and interpretation of results. J. Plankton Res. 19, $1637-1670$

Savinov, V. M. 1992: Spatial distribution of chlorophyll and primary production. Pp. 52-63 in: Phytoplankton of the Barents Sea. Russian Academy of Science. Apatity.

Slagstad, D. \& Støle-Hansen, K. 1991: Dynamics of plankton growth in the Barents Sea: model studies. Polar Res. 10, 173-186.

Smith, R. E. H. \& Herman, A. W. 1991: Productivity of sea ice algae: In situ vs, incubator methods. J. Mar. Syst. 2, 97-110.

Smith, R. E. H., Anning, J., Clement, P. \& Cota, G. 1988: Abundance and production of ice algae in Resolute Passage, Canadian Arctic. Mar. Ecol. Prog. Ser. 48, 251-263.

Vinje, T. 1985: Drift, composition, morphology and distribution of the sea ice fields in the Barents Sea. Norsk Polarinst. Skr. $179 C, 1-26$.

Vinje, T. \& Finnekåsa, Ø. 1986: The ice transport through the Fram Strait. Norsk Polarinst. Skr. 186, 1-39.

Vinje, T. \& Kvambekk, A. S. 1991: Barents Sea drift ice characteristics. Polar Res. 10, 59-68.

Wadhams, P. 1981: The ice cover in the Greenland and Norwegian Seas. Rev. Geophys. Space Phys. 12, 345-393.

Wassmann, P. \& Slagstad, D. 1993: Seasonal and annual dynamics of particulate carbon flux in the Barents Sea. Polar Biol. 13, 363-372. 